University of Nebraska - Lincoln

DigitalCommons@University of Nebraska - Lincoln

\title{
Planting date and development of spring-seeded irrigated canola, brown mustard and camelina
}

\author{
A. Pavlista \\ University of Nebraska, PREC, Scottsbluff, NE, apavlista@unl.edu \\ T. Isbell \\ USDA-ARS, Peoria, IL, Terry.Isbell@ars.usda.gov \\ D. D. Baltensperger \\ Texas A\&M University, College Station, dbaltensperger@tamu.edu \\ G. W, Hergert \\ University of Nebraska, PREC, Scottsbluff, NE, ghergert1@unl.edu
}

Follow this and additional works at: https://digitalcommons.unl.edu/panhandleresext

Part of the Agriculture Commons

Pavlista, A.; Isbell, T.; Baltensperger, D. D.; and Hergert, G. W, "Planting date and development of springseeded irrigated canola, brown mustard and camelina" (2011). Panhandle Research and Extension Center. 52 .

https://digitalcommons.unl.edu/panhandleresext/52

This Article is brought to you for free and open access by the Agricultural Research Division of IANR at DigitalCommons@University of Nebraska - Lincoln. It has been accepted for inclusion in Panhandle Research and Extension Center by an authorized administrator of DigitalCommons@University of Nebraska - Lincoln. 


\title{
Planting date and development of spring-seeded irrigated canola, brown mustard and camelina
}

\author{
A.D. Pavlista ${ }^{\mathrm{a}, *}$, T.A. Isbell $^{\mathrm{b}}$, D.D. Baltensperger ${ }^{\mathrm{c}}$, G.W. Hergert ${ }^{\mathrm{a}}$ \\ a University of Nebraska, PREC, 4502 Avenue I, Scottsbluff, NE 69361, United States \\ b USDA-ARS, Peoria, IL 61604, United States \\ ' Texas AE'M University, College Station, TX 77843, United States
}

\section{A R T I C L E I N F O}

\section{Article history:}

Received 8 July 2010

Received in revised form 19 October 2010

Accepted 28 October 2010

Available online 26 November 2010

\section{Keywords:}

Nebraska Panhandle

Oilseed crops

Omega-3

Omega-6

Omega-9

Erucic acid

Biofuel

\begin{abstract}
A B S T R A C T
With increased emphasis on bio-diesel fuels, the influence of spring planting on development of brown mustard (Brassica juncea cv. Arid), canola (B. napus cv. Hyola 401) and camelina (Camelina sativa cv. Boa) has become important. Field trials were conducted at Scottsbluff, NE, in 2005 and 2006 at planting dates of 24 February, 24 March, 7 April, 21 April and 5 May, and 3 March, 3 April, 10 April, 27 April, 11 May, and 2 Jun, respectively. Emergence time was shorter with later planting. Flowering date was later with later planting but occurred within a range of degree days (P-days). Fruiting was affected by date and P-days, but seed maturity was not affected by planting date and was unrelated to P-days. Fleabeetle (Phyllotreta spp.) damage was very high in brown mustard and canola. Bird, primarily house finch (Carppodacus mexicanus), feeding was a major problem with brown mustard planted before mid April and in canola, only with the first planting. Camelina was not affected by either. Planting in April gave the best yields, and canola could yield over $2200 \mathrm{~kg} \mathrm{ha}^{-1}$. Oil content of the Brassica was highest when planted from late March and later. For camelina, planting date had no effect. In brown mustard and canola, 60-65\% of oil was C18:1, in camelina, about 15\%. Later planting increased C18:1 content for the three crops. The second fatty acid was C18:2 with 20\% in brown mustard, $18 \%$ in canola and 20\% in camelina. Later planting increased C18:2 in camelina only. The major fatty acid in camelina was C18:3 at 32-37\%; earlier planting increased the content of $\mathrm{C} 18: 3$. In Camelina, $\mathrm{C} 20: 1$ comprised about $12 \%$ of the oil and was highest with April planting. Canola and camelina seeded in April could be grown for oil successfully in western Nebraska.
\end{abstract}

(C) 2010 Elsevier B.V. All rights reserved.

\section{Introduction}

The mustard family produces seed that is rich in oil which has been demonstrated to be useful in bio-diesel and green diesel. Because of the high oil contents $>30 \%$ when compared to commodity crops like soybean (oil content, 19\%) along with reduced inputs for production the mustard's show potential economic advantages. In addition, the Brassica's lower water use requirements over commodity crops that might be grown provide a distinct agronomic and environmental advantage. Brown mustard (Brassica juncea) and canola (Brassica napus) may offer the best overall potential for industrial and food use with higher levels of oleic acid and less polyunsaturated fatty acids. These fatty acid profiles offer increased oxidative stability compared to a soybean oil with high levels of saturates and linolenic acid. Camelina however, has high levels of polyunsaturates which is detrimental to long term storage, but

\footnotetext{
* Corresponding author. Tel.: +1 308632 1240; fax: +1 3086321365

E-mail address: apavlista@unl.edu (A.D. Pavlista).
}

hydro-treating and thermal cracking is indifferent to these poor chemical properties since all of the fatty acids are reduced and cracked to shorter branched alkanes making this suitable for green diesel.

With an increased emphasis on searching for a diesel substitute, the importance of oil seed crops is expected to increase in the USA. Brown mustard, canola and camelina (Camelina sativa) are potential bio-diesel crops (Bernardo et al., 2003; Bhardwaj, 2007) whose acreage is anticipated to increase in the High Plains (Johnston et al., 2002; Pileram et al., 2007). Brown mustard, canola and camelina are relatively new to the High Plains and have been grown mostly for vegetable and industrial oils, bird feed and spices. Spring planting of these crops would fit very well in the regions winter wheat rotations. Although production guides are available for the Brassica in this region (Baltensperger et al., 2004; Boyles et al., 2006), there is minimal data on their growth and development pattern (Angadi et al., 2004; Johnston et al., 2002). Although spring planting of these crops may have economic advantages (Clayton et al., 2004), there are few studies on planting dates (Johnson et al., 1995; Kirkland and Johnson, 2000). Furthermore, damage caused by fleabeetles (Phyllotreta spp.) when spring planted (Dosdall and Stevenson, 2005) 
Table 1

Rainfall and irrigation in April through July at Scottsbluff, NE, in 2005 and 2006 compared to long-term averages.

\begin{tabular}{lrrrrr}
\hline & $\begin{array}{l}\text { April } \\
(\mathrm{mm})\end{array}$ & May & June & July & Total \\
\hline 2005 & & & & & \\
$\quad$ Rainfall & 48 & 52 & 86 & 23 & 209 \\
$\quad$ Irrigation & 6 & 42 & 18 & 25 & 91 \\
$\quad$ Monthly & 54 & 94 & 104 & 48 & 300 \\
2006 & & & & & \\
$\quad$ Rainfall & 17 & 28 & 96 & 6 & 147 \\
$\quad$ Irrigation & 31 & 71 & 13 & 104 & 219 \\
$\quad$ Monthly & 48 & 99 & 109 & 110 & 366 \\
$\begin{array}{l}\text { Long term average } \\
\text { Rainfall }\end{array}$ & 46 & 83 & 79 & 65 & 273 \\
\hline
\end{tabular}

and by local birds primarily house finch (Carppodacus mexicanus) are concerns.

\section{Materials and methods}

Trials were conducted in 2005 and 2006 on brown mustard cv. Arid, canola cv. Hyola401 and camelina cv. Boa at the Panhandle Research \& Extension Ctr., Scottsbluff, NE $\left(41^{\circ} 50^{\prime} \mathrm{N}, 103^{\circ} 41^{\prime} \mathrm{W}\right.$, elevation $1208 \mathrm{~m}$ ). Soil was a Tripp fine sandy loam at $\mathrm{pH} 7.8$ and organic matter content of $0.9 \%$. The seeding rate was about 200 plants $/ \mathrm{m}^{2}$ or $7-9 \mathrm{~kg}$ seed/ha in 2005 and 2006. Seed was planted about $2 \mathrm{~cm}$ deep. Urea (21-0-0) was applied to plots in March to achieve $45 \mathrm{~kg} \mathrm{~N} / \mathrm{ha}$. Irrigation was supplied from an overhead, linear-move, sprinkler system and complimented rainfall (Table 1 ). Weed control was obtained by adding trifluralin (Treflan $4 \mathrm{~L}$ at $1.6 \mathrm{l} / \mathrm{ha}$ ). No fungicides were applied. Planting dates in 2005 were 24 February, 24 March, 7 April, 21 April, and 5 May, corresponding to calendar days of $55,83,97,111$, and 125 . In 2006, the planting dates were 3 March, 3 April, 10 April, 27 April, 11 May, and 2 June, corresponding to calendar days of $62,93,100$, 117, 131, and 153. Flea beetle (Phyllotreta spp.) and bird, primarily house finch (C. mexicanus), damages were assessed. However, in 2006, imidacloprid (Merit at 2.5 l/ha) was applied for flea beetle control. Four-row plots, $0.3 \mathrm{~m}$ wide and $3.2 \mathrm{~m}$ long, were harvested at maturity between 27 July and 5 August. To compare planting dates, height, development stages, damages, yield, oil content, and fatty acid distribution were measured.

Data on rain, air temperature, and soil temperature $10 \mathrm{~cm}$ below surface (Table 2, Fig. 1) were collected from a weather station located next to the field and monitored by the High Plains Climate Center (Changnon et al., 1990). Physiological days, P-days, were calculated from the daily air temperatures to estimate plant age at major developmental events (Sands et al., 1979, Pavlista

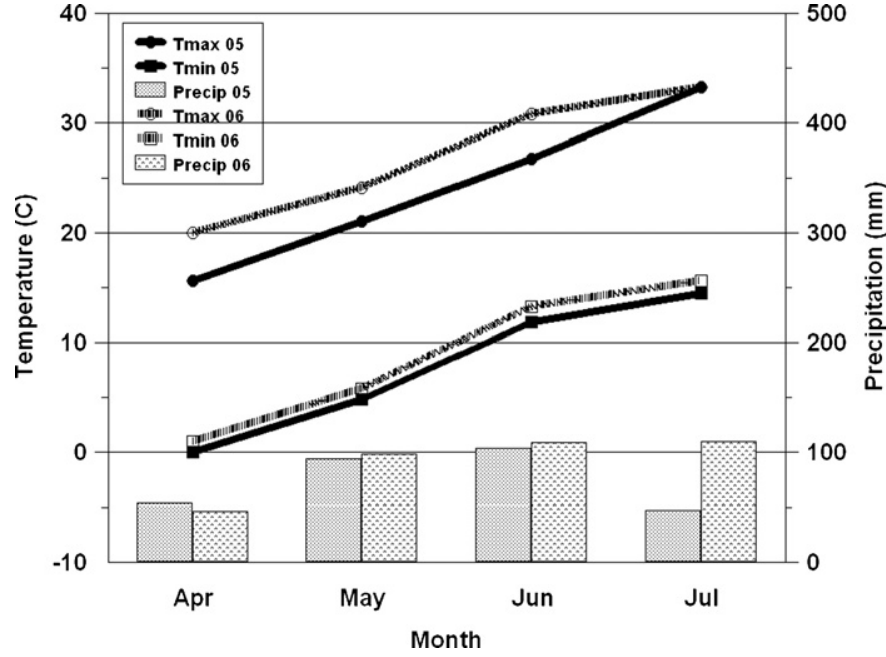

Fig. 1. Maximum $\left(T_{\max }\right)$ and minimum $\left(T_{\min }\right)$ temperatures and precipitation at Scottsbluff, NE, in 2005 and 2006.

and Gall, 2010). Flowering date was recorded when over 90\% of plants had flowered. Fruiting date was recorded when over $90 \%$ of plants had pods. Maturity date was recorded when the seeds were mature enough to harvest. Seed were mature when they were hard, and their color was no longer green (dark yellow or tan for brown mustard, maroon or brown for canola, and dark orange or rust for camelina).

Four replicated plots were used in the planting date study in 2005 and 2006. A factorial design was used to allow comparison of crops and planting dates. Data were analyzed using Proc ANOVA (SAS Inst, 2003) and means were separated by least significant differences.

Fatty acid and oil content analyses were conducted according to Pavlista et al. (2010).

\section{Results}

Seeds of all three crops planted at the earliest date did not emerge until after 3 WAP (Table 3 ); full emergence occurred by 3 WAP when planted on 24 March and 3 April. As planting was later, emergence occurred sooner (Table 3). With the first planting dates (24 February and 3 March), stands for the three crops were low, 40-65\% (data not shown). The stand for other planting dates were $90-100 \%$. Low planting temperature has been reported to delay germination and seedling growth of canola (Nykiforuk and Johnson-Flanagan, 1994). Canopy height was taken on 27 July 2005 and showed that, for the two Brassica sp., plants were tallest

Table 2

Soil and air temperature at planting and during the week after planting brown mustard, canola and camelina at Scottsbluff, NE, in 2005 and 2006.

\begin{tabular}{|c|c|c|c|c|}
\hline \multirow[t]{2}{*}{ Planting date } & \multicolumn{2}{|c|}{ Soil temperature at $10 \mathrm{~cm}$ depth average $\left({ }^{\circ} \mathrm{C}\right)$} & \multicolumn{2}{|c|}{ Air temperature average $\left({ }^{\circ} \mathrm{C}\right)$} \\
\hline & On day of planting & During week after planting & On day of planting & During week after planting \\
\hline \multicolumn{5}{|l|}{2005} \\
\hline 24 February & 2.2 & 2.8 & 2.2 & 2.2 \\
\hline 24 March & 3.9 & 6.1 & -2.2 & 4.4 \\
\hline 7 April & 10.6 & 3.9 & 9.4 & 8.3 \\
\hline 21 April & 8.3 & 10.0 & 4.4 & 6.1 \\
\hline 5 May & 14.4 & 13.9 & 13.3 & 11.7 \\
\hline \multicolumn{5}{|l|}{2006} \\
\hline 3 March & 5.6 & 5.6 & 7.2 & 5.6 \\
\hline 3 April & 10.0 & 10.6 & 10.6 & 10.0 \\
\hline 10 April & 13.3 & 15.6 & 13.9 & 13.9 \\
\hline 27 April & 13.9 & 13.9 & 12.8 & 11.7 \\
\hline 11 May & 13.3 & 17.8 & 9.4 & 13.3 \\
\hline 2 June & 22.8 & 25.0 & 23.9 & 23.9 \\
\hline
\end{tabular}


Table 3

Emergence, height, and damage of brown mustard, canola and camelina as influenced by planting date expressed in calendar days at Scottsbluff, NE, in 2005 and 2006.

\begin{tabular}{|c|c|c|c|c|c|}
\hline \multicolumn{2}{|c|}{ Planted calendar day } & \multirow[t]{2}{*}{ Ful emergence WAPa } & \multirow[t]{2}{*}{ Canopy height $\mathrm{t}^{\mathrm{b}} \mathrm{cm}$} & \multirow[t]{2}{*}{ Fleabeetle damage $e^{\mathrm{c}, \mathrm{d}, \mathrm{e}}$} & \multirow[t]{2}{*}{ Bird damage $^{\mathrm{e}}(\%)$} \\
\hline 2005 & 2006 & & & & \\
\hline \multicolumn{6}{|c|}{ Brassica juncea (brown mustard) } \\
\hline 55 & 62 & $5.0 \mathrm{~A}$ & 99 B & 4 & $62 \mathrm{~A}$ \\
\hline 83 & 93 & $3.0 \mathrm{~B}$ & $111 \mathrm{~A}$ & 4 & $34 \mathrm{~B}$ \\
\hline 97 & 100 & $2.6 \mathrm{C}$ & $115 \mathrm{~A}$ & 4 & $29 \mathrm{~B}$ \\
\hline 111 & 117 & $2.0 \mathrm{D}$ & $100 \mathrm{~B}$ & 3.75 & $5 \mathrm{C}$ \\
\hline 125 & 131 & $1.9 \mathrm{D}$ & $93 \mathrm{~B}$ & 3.50 & $0 \mathrm{C}$ \\
\hline \multicolumn{6}{|c|}{ Brassica napus (canola) } \\
\hline 55 & 62 & $5.0 \mathrm{~A}$ & $89 \mathrm{ABC}$ & $1.75 \mathrm{C}$ & $31 \mathrm{~A}$ \\
\hline 83 & 93 & $3.0 \mathrm{~B}$ & $96 \mathrm{~A}$ & $2.25 \mathrm{BC}$ & $0 \mathrm{~B}$ \\
\hline 97 & 100 & $2.6 \mathrm{C}$ & $94 \mathrm{AB}$ & $3 \mathrm{~A}$ & $0 \mathrm{~B}$ \\
\hline 111 & 117 & $2.0 \mathrm{D}$ & $86 \mathrm{BC}$ & $2.50 \mathrm{AB}$ & $0 \mathrm{~B}$ \\
\hline 125 & 131 & $2.0 \mathrm{D}$ & $84 \mathrm{C}$ & $2.25 \mathrm{BC}$ & $0 \mathrm{~B}$ \\
\hline \multicolumn{6}{|c|}{ Camelina sativa (camelina) } \\
\hline 55 & 62 & $5.0 \mathrm{~A}$ & 72 & $<1$ & 0 \\
\hline 83 & 93 & $3.0 \mathrm{~B}$ & 64 & 0 & 0 \\
\hline 97 & 100 & $2.8 \mathrm{BC}$ & 64 & 0 & 0 \\
\hline 111 & 117 & $2.0 \mathrm{D}$ & 67 & 0 & 0 \\
\hline 125 & 131 & $1.8 \mathrm{D}$ & 67 & 0 & 0 \\
\hline Planted date & & $* * \mathrm{f}$ & $*$ & ns & $* *$ \\
\hline Crop & & ns & $* *$ & $* *$ & $* *$ \\
\hline Date $\times$ crop & & ns & ns & ns & $* *$ \\
\hline
\end{tabular}

a $\mathrm{WAP}=$ weeks after planting.

b Final height taken one week before harvest.

c Fleabeetle damage was on a 0 (none)-4 (severe) scale.

d Fleabeetle damage was in 2005 but not in 2006 due to insecticide application.

e Damage was assessed two weeks before harvest. Data in each column for each crop followed by the same capital letter were not significantly different at $P<0.05$.

f ${ }^{* * * *}$ Significant at $P<0.05$ and $P<0.01$, respectively; ns $=$ not significant.

when seed was planted between 24 March and 10 April (Table 3). Flowering dates for all three crops was later in calendar days corresponding with a later planting date (Table 4). This agreed with canola flowering date reported in Saskatchewan (Kirkland and Johnson, 2000). However, the P-days for this event did not differ regardless of planting date. Fruiting date was also later with later planting but there also was a trend to higher P-day accumulation. Seed maturity occurred at about the same date regardless of plant- ing date and showed a significant trend to requiring less P-days to accumulate (Table 4 ).

Flea beetle damage was assessed on a scale of 0 (none), 1 (slight), 2 (some), 3 (significant), and 4 (severe). Flea beetle feeding was most severe with brown mustard and significant with canola, but camelina was unaffected (Table 3). Plants seeded in April were the most sensitive. The sensitivity of spring-seeded canola has been noted in Canada (Dosdall and Stevenson, 2005). Bird damage

Table 4

Developmental stages of brown mustard, canola and camelina as influenced by planting date in calendar days at Scottsbluff, NE, in 2005 and 2006.

\begin{tabular}{|c|c|c|c|c|c|c|c|}
\hline \multicolumn{2}{|c|}{ Planted calendar day } & \multicolumn{2}{|c|}{ Flowering } & \multicolumn{2}{|l|}{ Fruiting ${ }^{\mathrm{a}}$} & \multicolumn{2}{|c|}{ Seed maturity ${ }^{\mathrm{b}}$} \\
\hline 2005 & 2006 & Cal. day & P-day & Cal. day ${ }^{\mathrm{c}}$ & P-day ${ }^{c}$ & Cal. day ${ }^{\mathrm{d}}$ & P-day ${ }^{d}$ \\
\hline \multicolumn{8}{|c|}{ Brassica juncea (brown mustard) } \\
\hline 55 & 62 & $151 \mathrm{~B}^{\mathrm{e}}$ & 241 & 160 & 309 & 195 & $543 \mathrm{~A}$ \\
\hline 83 & 93 & 153 B & 198 & 167 & 290 & 195 & $490 \mathrm{~B}$ \\
\hline 97 & 100 & $160 \mathrm{AB}$ & 215 & 174 & 314 & 195 & $461 \mathrm{BC}$ \\
\hline 111 & 117 & $163 \mathrm{AB}$ & 198 & 181 & 341 & 195 & $429 \mathrm{CD}$ \\
\hline 125 & 131 & $171 \mathrm{~A}$ & 224 & 194 & 398 & 198 & $410 \mathrm{D}$ \\
\hline \multicolumn{8}{|c|}{ Brassica napus (canola) } \\
\hline 55 & 62 & $147 \mathrm{C}$ & 208 & 160 & 309 & 194 & 560 \\
\hline 83 & 93 & $155 \mathrm{BC}$ & 211 & 167 & 290 & 194 & 491 \\
\hline 97 & 100 & $160 \mathrm{ABC}$ & 218 & 174 & 314 & 194 & 461 \\
\hline 111 & 117 & $163 \mathrm{AB}$ & 206 & 181 & 341 & 194 & 439 \\
\hline 125 & 131 & $172 \mathrm{~A}$ & 230 & 194 & 398 & 201 & 438 \\
\hline \multicolumn{8}{|c|}{ Camelina sativa (camelina) } \\
\hline 55 & 62 & $149 \mathrm{D}$ & 224 & 160 & 309 & 189 & $501 \mathrm{~A}$ \\
\hline 83 & 93 & $153 \mathrm{CD}$ & 198 & 160 & 290 & 190 & $456 \mathrm{AB}$ \\
\hline 97 & 100 & $159 \mathrm{BC}$ & 211 & 174 & 314 & 190 & $423 \mathrm{~B}$ \\
\hline 111 & 117 & $162 \mathrm{~B}$ & 195 & 181 & 341 & 190 & $410 \mathrm{~B}$ \\
\hline 125 & 131 & $172 \mathrm{~A}$ & 230 & 187 & 347 & 195 & 395 B \\
\hline Planted date & & $* * \mathrm{f}$ & ns & - & - & $*$ & $* *$ \\
\hline Crop & & ns & ns & - & - & $* *$ & $*$ \\
\hline Date $\times$ crop & & ns & ns & - & - & ns & ns \\
\hline
\end{tabular}

a $>90 \%$ of plants had flowered or had pods, respectively.

b $>90 \%$ of plants had hard seeds that were no longer green and ready for harvest.

c Since fruiting date was not recorded in 2005, statistical comparisons were not performed for either crop; data from 2006 were recorded.

d Since seed maturity was very late for B. napus in 2005 and not recorded, statistical comparisons were not performed; data for 2006 were recorded.

e Data in each column for each crop followed by the same capital letter were not significantly different at $P<0.05$.

f $\stackrel{* * * *}{*}$ Significant at $P<0.05$ and $P<0.01$, respectively; ns $=$ not significant. 
Table 5

Yield and oil content of brown mustard, canola and camelina as influenced by planting date expressed in calendar days at Scottsbluff, NE, in 2005 and 2006.

\begin{tabular}{|c|c|c|c|c|c|}
\hline \multicolumn{2}{|c|}{ Planted calendar day } & \multicolumn{2}{|c|}{ Yield (kg/ha) } & \multicolumn{2}{|c|}{ Oil content (\% dry weight) } \\
\hline 2005 & 2006 & 2005 & 2006 & 2005 & 2006 \\
\hline \multicolumn{6}{|c|}{ Brassica juncea (brown mustard) } \\
\hline 55 & 62 & $543 \mathrm{~B}^{\mathrm{a}}$ & 398 B & $32.4 \mathrm{~A}$ & $23.6 \mathrm{BC}$ \\
\hline 83 & 93 & $1101 \mathrm{~A}$ & $810 \mathrm{AB}$ & $32.8 \mathrm{~A}$ & $19.6 \mathrm{C}$ \\
\hline 97 & 100 & $820 \mathrm{AB}$ & $1239 \mathrm{~A}$ & $29.6 \mathrm{AB}$ & $29.0 \mathrm{AB}$ \\
\hline 111 & 117 & $794 \mathrm{AB}$ & $1211 \mathrm{~A}$ & $25.6 \mathrm{~B}$ & $28.9 \mathrm{AB}$ \\
\hline 125 & 131 & $887 \mathrm{AB}$ & $1277 \mathrm{~A}$ & $26.1 \mathrm{~B}$ & $36.4 \mathrm{~A}$ \\
\hline- & 153 & - & $896 \mathrm{AB}$ & - & $31.5 \mathrm{~A}$ \\
\hline \multicolumn{6}{|c|}{ Brassica napus (canola) } \\
\hline 55 & 62 & $955 \mathrm{~B}$ & $866 \mathrm{C}$ & $40.9 \mathrm{~A}$ & $34.2 \mathrm{~B}$ \\
\hline 83 & 93 & $1349 \mathrm{~A}$ & $2118 \mathrm{~A}$ & $41.0 \mathrm{~A}$ & $40.1 \mathrm{~A}$ \\
\hline 97 & 100 & $1061 \mathrm{~B}$ & $2261 \mathrm{~A}$ & $41.9 \mathrm{~A}$ & $39.5 \mathrm{~A}$ \\
\hline 111 & 117 & $402 \mathrm{C}$ & $2238 \mathrm{~A}$ & $37.6 \mathrm{~B}$ & $40.0 \mathrm{~A}$ \\
\hline 125 & 131 & $528 \mathrm{C}$ & $1927 \mathrm{AB}$ & $37.9 \mathrm{~B}$ & $38.9 \mathrm{~A}$ \\
\hline- & 153 & - & 1444 B & - & $37.7 \mathrm{~A}$ \\
\hline \multicolumn{6}{|c|}{ Camelina sativa (camelina) } \\
\hline 55 & 62 & $556 \mathrm{C}$ & 1037 B & 33.4 & 29.8 \\
\hline 83 & 93 & $1204 \mathrm{~A}$ & $1456 \mathrm{~A}$ & 34.3 & 29.8 \\
\hline 97 & 100 & $984 \mathrm{AB}$ & $1329 \mathrm{AB}$ & 34.0 & 30.4 \\
\hline 111 & 117 & $606 \mathrm{BC}$ & $1305 \mathrm{AB}$ & 32.0 & 31.7 \\
\hline 125 & 131 & $729 \mathrm{BC}$ & 967 B & 30.3 & 31.8 \\
\hline- & 153 & - & $189 \mathrm{C}$ & - & 29.3 \\
\hline Planted date & & \multicolumn{2}{|c|}{$* * \mathrm{~b}$} & \multicolumn{2}{|c|}{ ns } \\
\hline Crop & & \multicolumn{2}{|c|}{$* *$} & \multicolumn{2}{|c|}{$* *$} \\
\hline Date $\times$ crop & & \multicolumn{2}{|c|}{ ns } & \multicolumn{2}{|c|}{$*$} \\
\hline
\end{tabular}

a Data in each column for each crop followed by the same capital letter were not significantly different at $P<0.05$.

b *** Significant at $P<0.05$ and $P<0.01$, respectively; ns = not significant.

assessed two weeks before harvest was observed in brown mustard and was significantly worse with seeding between 24 February and 10 April (Table 4). For canola, bird damage occurred only when seeded on 24 February 2005 and 3 March 2006. Camelina was not affected by the birds in the Nebraska Panhandle. Yields varied slightly with planting date but was significantly lower in all three crops when seeded on 24 February or 3 March (Table 5). The most consistent planting dates for yield seemed to be from late March to late April agreeing with other locations in the High Plains on spring canola and brown mustard (Angadi et al., 2004;
Chen et al., 2005; Kirkland and Johnson, 2000; Pavlista et al., 2010). Canola showed significantly higher average yield, $1400 \mathrm{~kg} / \mathrm{ha}$, than the other two crops. There was no difference between brown mustard and camelina.

Planting date showed different effects on oil content between the 2 years but, when the years' data were combined, there was no significant effect for planting dates for either of the crops (Table 5). Combining crops, the average oil content for planting date ranged from 31.3 to $34.3 \%$ with no trend observable. The three crops did significantly differ in their oil content from each other (Table 5). Canola

Table 6

Fatty acid profile of brown mustard, canola and camelina as influenced by planting date in calendar days at Scottsbluff, NE, in 2005 and 2006

\begin{tabular}{|c|c|c|c|c|c|c|c|c|c|c|}
\hline \multicolumn{2}{|c|}{ Planted calendar day } & C $16: 0$ & C 18:0 & C $18: 1$ & C $18: 2$ & C $18: 3$ & C 20:0 & C $20: 1$ & C $20: 2$ & C $22: 1$ \\
\hline 2005 & 2006 & \multicolumn{9}{|l|}{$\%$ total oil } \\
\hline \multicolumn{11}{|c|}{ Brassica juncea (brown mustard) } \\
\hline 55 & 62 & 4.5 & 2.3 & $57.6 \mathrm{~B}^{\mathrm{a}}$ & 21.0 & $10.4 \mathrm{BC}$ & 0.6 & 1.4 & 0 & 0.7 \\
\hline 83 & 93 & 4.5 & 2.2 & 56.3 B & 21.0 & $10.5 \mathrm{BC}$ & 0.5 & 1.8 & 0 & 0.5 \\
\hline 97 & 100 & 4.2 & 2.0 & $57.0 \mathrm{~B}$ & 20.6 & $11.8 \mathrm{~A}$ & 0.6 & 1.6 & 0 & 0.7 \\
\hline 111 & 117 & 4.5 & 2.3 & $57.7 \mathrm{~B}$ & 21.0 & $11.1 \mathrm{AB}$ & 0.7 & 1.1 & 0 & 0.3 \\
\hline 125 & 131 & 4.3 & 2.2 & $60.2 \mathrm{~A}$ & 20.1 & $9.6 \mathrm{CD}$ & 0.7 & 1.6 & 0 & 0.2 \\
\hline- & 153 & 3.9 & 2.2 & $61.0 \mathrm{~A}$ & 19.3 & $9.0 \mathrm{D}$ & 0.8 & 1.3 & 0 & 0.7 \\
\hline \multicolumn{11}{|c|}{ Brassica napus (canola) } \\
\hline 55 & 62 & 3.9 & 2.4 & 64.6 & 18.0 & 8.8 & 0.6 & 1.4 & 0 & 0 \\
\hline 83 & 93 & 3.8 & 2.3 & 64.5 & 18.0 & 7.5 & 0.6 & 2.6 & 0 & 0 \\
\hline 97 & 100 & 3.9 & 2.4 & 65.0 & 17.8 & 8.2 & 0.6 & 1.4 & 0 & 0 \\
\hline 111 & 117 & 3.9 & 2.4 & 64.7 & 18.1 & 8.4 & 0.6 & 1.4 & 0 & 0 \\
\hline 125 & 131 & 3.8 & 2.4 & 65.6 & 17.6 & 8.8 & 0.6 & 0.6 & 0 & 0 \\
\hline- & 153 & 3.8 & 2.6 & 67.1 & 16.3 & 7.3 & 0.9 & 0.8 & 0 & 0 \\
\hline \multicolumn{11}{|c|}{ Camelina sativa (camelina) } \\
\hline 55 & 62 & 6.0 & 2.4 & $15.0 \mathrm{~B}$ & $19.5 \mathrm{~B}$ & $35.9 \mathrm{~A}$ & 1.9 & $12.2 \mathrm{~B}$ & 1.5 & 2.8 \\
\hline 83 & 93 & 6.0 & 2.5 & $15.1 \mathrm{~B}$ & $19.6 \mathrm{~B}$ & $37.1 \mathrm{~A}$ & 1.6 & $12.0 \mathrm{~B}$ & 1.2 & 2.5 \\
\hline 97 & 100 & 6.0 & 2.5 & $15.1 \mathrm{~B}$ & $19.1 \mathrm{~B}$ & $36.3 \mathrm{~A}$ & 1.5 & $12.8 \mathrm{~A}$ & 1.5 & 2.9 \\
\hline 111 & 117 & 5.8 & 2.4 & $14.9 \mathrm{~B}$ & $18.9 \mathrm{~B}$ & $35.9 \mathrm{~A}$ & 1.9 & $12.8 \mathrm{~A}$ & 1.5 & 3.0 \\
\hline 125 & 131 & 6.0 & 2.5 & $16.2 \mathrm{~A}$ & $21.1 \mathrm{~A}$ & 32.9 B & 2.0 & $12.3 \mathrm{AB}$ & 1.3 & 2.8 \\
\hline- & 153 & 5.9 & 2.5 & $15.7 \mathrm{~A}$ & $21.0 \mathrm{~A}$ & $32.0 \mathrm{~B}$ & 2.1 & $11.8 \mathrm{~B}$ & 1.6 & 3.1 \\
\hline Date & & $n s^{b}$ & ns & $* *$ & ns & $*$ & ns & ns & ns & ns \\
\hline Crop & & $* *$ & $* *$ & $* *$ & $* *$ & $* *$ & $* *$ & $* *$ & $* *$ & $* *$ \\
\hline Date $\times$ crop & & ns & ns & ns & $*$ & ns & ns & ns & ns & ns \\
\hline
\end{tabular}

a Data in each column for each crop followed by the same capital letter were not significantly different at $P<0.05$.

b ${ }^{* * * *}$ Significant at $P<0.05$ and $P<0.01$, respectively; ns = not significant. 
averaged across planting dates $38.8 \%$ oil while camelina averaged $31.1 \%$ and brown mustard $28.5 \%$.

For the two Brassica, the major fatty acid in the oil was C18:1, comprised primarily of oleic acid (C18:1 d9). The three crops were significantly different from each other on their amount of C18:1. In canola, C18:1 accounted for $65 \%$ of the oil and was not significantly affected by planting date (Table 6). The C18:1 in brown mustard accounted for $58 \%$ of oil and was affected by planting date; seeding in May gave over 60\% C18:1. Camelina was relatively low in this fatty acid with $15 \%$ but the amount was also affected by planting date with later seeding giving higher C18:1 content (Table 6). The second major component of oil in the Brassica was linoleic acid (C18:2) which showed no significant difference resulting from planting date (Table 6 ). Linoleic acid was also the second major component in camelina oil at $20 \%$. In camelina, the later planting dates had the highest amount with $21 \%$ (Table 6 ). The major fatty acid in camelina was linolenic acid (C18:3), commonly referred to as 'omega-3,' which comprised 35\% of the oil (Table 6). The three later planting dates had the lowest amount. Brown mustard had 11\% C18:3 and was significantly higher than the $8 \%$ in canola. This fatty acid was highest in brown mustard when planted in April (Table 6). Planting date did not affect C18:3 content in canola. Another major fatty acid in camelina was C20:1 which accounted for $12 \%$ of the oil and was highest when seeding was in April (Table 6). Another fatty acid of interest was erucic acid (C22:1) which was present in low amounts, 3\%, in camelina (Table 6).

\section{Discussion}

In general, seeding in April gave the best results for brown mustard, canola and camelina for a combination of yield, oil content, fatty acid profile, and pest damage. Several studies have shown the importance of planting date on canola growth, flowering time and yield in Canada (Angadi et al., 2004; Chen et al., 2005; Gusta et al., 2004). In Saskatchewan, Gusta et al. (2004) reported that plants derived from seed harvested from April seeding were healthier and resulted in greater yield than plants grown from seed harvested from May-seeded plants. In Montana, planting date by mid-April was reported as optimal (Chen et al., 2005). Soil temperature at planting may play an important role in seed germination and emergence (Nykiforuk and Johnson-Flanagan, 1994). Temperature was recorded with probes placed $10 \mathrm{~cm}$ below the surface. This was, however, $8 \mathrm{~cm}$ lower than where seed was placed. In general, as seeds were planted later, the soil and air temperatures tended to be warmer and 2006 was warmer than 2005 (Table 2, Fig. 1). Although the cold temperatures in March may have delayed germination, there was little correlation between soil at $10 \mathrm{~cm}$ and air temperatures to time to emergence when comparing the 2 years. A similar observation was reported on spring canola grown across the US High Plains (Pavlista et al., 2010).

Since yield in Scottsbluff, NE, varied greatly between 2005 and 2006, temperature was analyzed on a monthly basis for the growing season, April through July (Fig. 1). These conditions were below normal in 2005 for April, May and June, but in 2006, temperature was above normal for these months. The average temperature deviation for these three months in 2006 was $1.8^{\circ} \mathrm{C}$ above normal while in 2005 , the deviation was $1.0^{\circ} \mathrm{C}$ below normal. The 2006 season was warmer than the 2005 season by $2.8^{\circ} \mathrm{C}$ (Fig. 1). In Saskatchewan, seeding canola in early-mid spring was best under conditions of a moist spring but mid-late spring seeding was best when spring was drier (Angadi et al., 2004). Rain in April and May differed considerably with $100 \mathrm{~mm}$ falling in 2005 versus $45 \mathrm{~mm}$ in 2006 (Table 1). Therefore in 2006, there was greater irrigation in April, May and July (Table 1). Total precipitation for the four-month growing season was $300 \mathrm{~mm}$ in 2005 and $366 \mathrm{~mm}$ in 2006 with precipitation more evenly spread over the months in 2006 than in 2005 (Fig. 1). Growing conditions were warmer and wetter in 2006 than in 2005 (Fig. 1). Angadi et al. (2004) concluded that good early spring moisture in April and May favored early spring planting for canola yield. Whereas, moisture in June and July favored planting in June. Data reported here concurred for brown mustard and camelina as well as for canola.

Using linear regression (SAS Inst, 2003), the occurrence of developmental stages were analyzed with respect to physiological days (P-days). Flowering occurred at about 210 P-days (Table 4) regardless of planting date or year conditions $\left(r^{2}=0.02\right)$. There was no difference between the three crops. The relation between the length of time to flower reported by Chen et al. (2005) may be more related to temperature (P-days) and rain than to actual time. Seed maturity, on the other hand, occurred on the same date regardless of planting time (Table 4 ) and required less P-days when planted later $\left(r^{2}=0.80\right)$. Camelina seed matured earlier than the two Brassica planted on the same date and required less P-days (Table 4).

Oil content was highest in canola and both Brassica were affected by planting date. The same pattern as observed with seed yield was observed with oil content (Table 5). In 2005, more oil was attained with earlier planting while in 2006, higher oil came from later planting in spring. As with seed yield, this may be due to the yearly differences in temperature and rain (Fig. 1). Camelina seemed not to be affected by planting date. The direct relation between seed yield and oil content for canola and brown (Indian) mustard reported in Australia (Gunasekera et al., 2006) was not observed here. Hamama et al. (2003) reported that canola cultivars contained an average of $39.4 \%$ oil and that the primary fatty acids were C18:1 (containing oleic acid) comprised an average of $63.5 \%$ of the oil. The other two major fatty acids were C18:2 (19.5\%) and C18:3 (8.1\%). These findings agree with those reported here (Table 6). Robinson (1987) reported that the major four fatty acids in camelina were $\mathrm{C} 18: 3$ (27.9\%), C18:2 (18.7\%), C18:1 (17.5\%), and C20:1 (16.4\%). The analyses of the Scottsbluff camelina seed showed higher C18:3 and $\mathrm{C} 18: 2$ but less $\mathrm{C} 18: 1$ and $\mathrm{C} 20: 1$ than were reported in Minnesota (Table 6). The oil content and fatty acid profile is important for the commercialization of oilseed for bio-fuels as well as for food and industrial uses (Bhardwaj, 2007; Pileram et al., 2007).

Oil content was nearly independent of the planting date and fell within the average oil values for these three crops grown in different regions. Canola demonstrated the highest average oil content and yield compared to brassica napus and camelina sativa. However, canola is a plant that has had significantly more development effort for genetic improvements compared to the other two crops evaluated for this growing region. Fatty acid profiles for brassica juncea and brassica napus were similar with both crops demonstrating mid oleic acid levels from 56 to $67 \%$ oleic. The higher oleic contents of these seed oils make them attractive for a multitude of food and industrial uses were good oxidative stability is required. The low levels of saturated fatty acid in brassica napus and brassica juncea will impart improved cold temperature performance in fuels and lubricants were cloud and pour points are typically very poor for vegetable oils especially when compared to oils with high levels of saturated fatty acids like soybean oil. Camelina has very high levels of linolenic acid which makes this oil particularly susceptible to oxidation. This coupled with higher levels of saturates and 3\% erucic acid will limit the use of this oil to industrial applications that can tolerate hydrogenation of the oil to improve its oxidative stability. Hydrotreating and thermal cracking for production of green diesel would also be well suited for camelina oil. 


\section{Conclusion}

Spring planting of brown mustard, canola and camelina in western Nebraska would be recommended in April but moisture and soil temperature conditions for spring influences what part of the month.

\section{References}

Angadi, S.V., Cutforth, H.W., McConkey, B.G., Gan, Y., 2004. Early seeding improves the sustainability of canola and mustard production on the Canadian semiarid prairie. Can. J. Plant Sci. 84, 705-711.

Baltensperger, D.D., Lyon, D.J., Burgener, P.A., Hein, G.L., Harveson, R.M., Yonts, C.D. Margheim, J.F., Frickel, G.E., Foster, G.J., 2004. Brown Mustard Production. U. Nebraska Coop Ext Circ \#04-183.

Bernardo, A., Howard-Hildige, R., O'Connell, A., Nichol, R., Ryan, J., Rice, B., Roche, E., Leahy, J.J., 2003. Camelina oil as a fuel for diesel transport engines. Ind. Crops Prod. 17, 191-197.

Bhardwaj, H.L., 2007. Utilizing locally-produced canola to manufacture biodiesel. In: Janick, J., Whipkey, A. (Eds.), Issues in New Crops and New Uses. ASHS Press, Alexandria, VA, pp. 43-46.

Boyles, M., Peeper, T., Stamm, M., 2006. Great Plains Canola Production Handbook. Kansas State U. MF-2734.

Changnon, S.A., Lamb, P., Hubbard, K.G., 1990. Regional climate denters: new institutions for climate services and climate-impact research. Bull. Am. Meteorol. Soc. 71, 527-537.

Chen, C., Jackson, G., Karnes, N., Wichman, D., Johnson, G., Johnson, D., 2005. Determining the feasibility of early seeding canola in the northern Great Plains. Agron. J. 97, 1252-1262.

Clayton, G.W., Harker, K.N., O’Donovan, J.T., Blackshaw, R.E., Dosdall, L.M., Stevenson, F.C., Ferguson, T., 2004. Fall and spring seeding date effects on herbicide-tolerant canola (Brassica napus L.) cultivars. Can. J. Plant Sci. 84, 419-430.

Dosdall, L.M., Stevenson, F.C., 2005. Managing flea beetle (Phyllotreta spp.) (Coleoptera: Chrysomelidae) in Canada with seeding date, plant density, and seed treatment. Agron. J. 97, 1570-1578.
Gunasekera, C.P., Martin, L.D., Siddique, K.H.M., Watson, G.H., 2006. Genotype by environment interactions of Indian mustard (Brassica juncea L.) and canola (Brassica napus L.) in Mediterranean-type environments II. Oil and protein concentraions in seed. Eur. J. Agron. 25, 13-21.

Gusta, L.V., Johnson, E.N., Nesbitt, N.T., Kirkland, K.J., 2004. Effect of seeding date on canola seed quality and seed vigour. Can. J. Plant Sci. 84, 463-471.

Hamama, A.A., Bhardwaj, J.L., Starner, D.E., 2003. Genotype and growing location effects on phytosterols in canola oil. JAOCS 80, 1121-1126.

Johnson, B.L., McKay, K.R., Schneiter, A.A., Hanson, B.K., Schatz, B.G., 1995. Influence of planting date on canola and crambe production. J. Prod. Agric. 8, 594599.

Johnston, A.M., Tanaka, D.L., Miller, P.R., Brandt, S.A., Nielsen, D.C., Lafond, G.F., Riveland, N.R., 2002. Oilseed crops for semiarid cropping systems in the northern Great Plains. Agron. J. 94, 231-240.

Kirkland, K.J., Johnson, E.N., 2000. Alternative seeding dates (fall and April) affect Brassica napus canola yield and quality. Can. J. Plant Sci. 80, 713719.

Nykiforuk, C.L., Johnson-Flanagan, A.M., 1994. Germination and early seedling development under low temperature in canola. Crop. Sci. 34, 1047-1054.

Pavlista, A.D., Gall, C., 2010. Delaying early blight onset in potato with thidiazuron. Am. J. Potato Res., in press, doi:10100/s12230-010-9168-X.

Pavlista, A.D., Santra, D.K., Isbell, T.A., Baltensperger, D.D., Hergert, G.H., Krall, J. Mesbach, A., Johnson, J., O’Neil, M., Aiken, R., Barada, A., 2010. Adaptability of irrigated spring canola (Brassica napus) oil production to the US High Plains. Ind. Crops Products, in press, doi:10.1016/j.indcrop.2010.10.005.

Pileram, A.L., Sands, D.C., Boss, D., Dale, N., Wichman, D., Lamb, P., Lu, C., Barrows, R., Kirkpatrick, M., Thompson, B., Johnson, D.L., 2007. Camelina sativa, a Montana omega-3 and fuel crop. In: Janick, J., Whipkey, A. (Eds.), Issues in New Crops and New Uses. ASHS Press, Alexandria, VA, pp. 129-131.

Robinson, R.G., 1987. Camelina: a useful research crop and a potential oilseed crop. Minn. Ag. Exp. Sta. Bull. 579 (item no. AD-SB-3275).

Sands, P.J., Hackett, C., Nix, H.A., 1979. A model of the development and bulking of potatoes (Solanum tuberosum L.). I. Derivation from well-managed field croops. Field Crops Res. 2, 309-331.

SAS Institute, 2003. SAS System for Windows. Release 9. 1. SAS Institute Inc., Cary, NC. 